\title{
New Editions
}

A Text-Book of Histology. By H. E. Jordan, A.M., Ph.D. Third Edition. Pp. 857. London: D. Appleton \& Co. 1924. Price 25 s. net.

We have favourably reviewed the previous editions of this handsome volume and need do little more than say that the present one fully maintains the high standard of its predecessors. There is a full and accurate account of the microscopic structure of the body and the practical directions are excellent. The beginner may find some passages rather hard reading, but he will certainly find enough to assuage his thirst for knowledge.

Lippincott's Quick Reference Book for Medicine and Surgery. Systematised by George E. Rehberger, A.B., M.D. Fourth Edition.

London: J. B. Lippincott Company. Price 65s. net.

In the April number of the Journal for this year there is a notice of the third edition of this work, and now we have the "fourth edition revised." The book is essentially a work of reference, intended for the use of the busy and isolated practitioner. For such a large volume references are wonderfully, quickly, and easily made, and with the aid of the thumb-nail index to the eleven parts into which the book is divided, the alphabetical subdivision of each part and the generous system of cross references.

In this present edition over forty subjects have been reconsidered, besides the making of other minor changes in the volume. The book is well got up and illustrated, and is likely to be of value to those doctors for whom it is specially intended.

\section{NOTES ON BOOKS}

The six articles composing The Advance of Orthopadic Surgery, by A. H. Tubby, C.B., C.M.G. (H. K. Lewis \& Co., price 7s. 6d.) are reprinted from the Clinical Journal. They make interesting and instructive reading for all engaged in the surgery of the locomotory apparatus. The whole range of orthopædics is passed in detailed review. Congenital and growth deformities; static and postural conditions; infantile and spastic paralysis; reconstructive surgery and the problem of the cripple, are the main subjects dwelt upon. The bibliography provided is valuable. An important feature is the account given of several reconstructive procedures which the author himself has devised with reference to congenital dislocation of the hip and the paralysis of anterior poliomyelitis.

Fundamentals of Human Physiology, by R. G. Pearce, and J. J. R. Macleod, assisted by Norman B. Taylor, third edition (Henry Kimpton, 


\section{Notes on Books}

price I8s.), is intended primarily for non-medical readers who are proceeding to appointments in the Public Health and allied services. The scope covered is fairly comprehensive, but the limited size of the book precludes the subject from being dealt with in a detailed manner. After a preliminary survey of the anatomy and structure of the body, the grouping of the matter follows the usual procedure common to text-books on physiology, the subjects of dietetics and metabolism receiving special consideration. An appendix contains some useful information and advice regarding public and personal hygiene, and enumerates the more practical sanitary considerations to be observed in the commoner infectious diseases. We are surprised to find in a book emanating from the Toronto School that insulin is disposed of in four lines, and is not even mentioned in the index. An unfortunate slip in the alignment on p. I9I, informs the reader that trypsinogen splits neutral fat into fatty acid and glycerin, and that lipase converts all starches into maltose!

A book which tends to diminish the pessimism which surrounds epilepsy is to be welcomed. Clinical Studies in Epilepsy, by Donald Fraser (E. \& S. Livingstone, price $7 \mathrm{~s}$. 6d.), is an attempt to shed some light on the meaning and mechanism of the epileptic fit. From his wide experience of migraine and the epilepsies, the author revives, with some modification, the old theory of vaso-constriction. $\mathrm{He}$ believes that this is an essential factor in determining the actual attack and that it may be brought about by an unknown toxin, the result either of the breaking down of cerebral tissue or of the accumulation of the ordinary products of tissue waste. There is an interesting chapter dealing with the relation of hypopituitarism to epilepsy. Numerous cases are cited in support of the author's contentions. The book is readably written and contains much suggestive matter.

The second edition of Ancesthesia, by James T. Gwathmey, M.D. (J. \& A. Churchill, price $25 \mathrm{~s}$.), has been improved by the omission of some chapters, the contents of which having been once published, do not justify their appearance again. The space thus gained has been made use of for bringing the book up-to-date, so that it contains much that is new of a scientific and practical nature. A wealth of detailed and accurate information is presented in a readable way. There are the usual chapters on the history of the art, accompanied by portraits, and on general and special physiology, and these are followed by a detailed account of the various anæsthetic agents, including ethylen, and the methods of administering them. The author has enlisted the aid of experts who have written special sections, such as those on intra-tracheal insufflation, local anæsthesia, spinal analgesia, and dental analgesia. Although British investigations and practice are not ignored, the book is essentially American, and 


\section{Books Received}

herein lies its greatest interest for the British reader. It is well written, clearly printed and copiously illustrated, and can be recommended as one of the best on the subject.

We have received three useful practical books for nurses: Elementary Hygiene, and edition, by H. C. R. Darling (J. \& A. Churchill, price 4s. 6d.); Elementary Science, by W. F. Lloyd (J. \& A. Churchill, price 3s. 6d.); and Materia Medica, by A. L. Muirhead and Edith P. Brodie (Henry Kimpton, price ros. 6d.).

\section{BOOKS RECEIVED}

Bainbridge, William Seaman. Report on Second International Congress of Military Medicine and Pharmacy. Rome, May-June, I923 • • • . (Reprinted from The Military Surgeon) BARTON, E. A. Essentials of Infant Feeding.

Boyd, William. Surgical Pathology. (H. K. Lewis \& Co., Ltd.) 3s. 6d. net.

(W. B. Saunders Company, Ltd.)

Cameron, Samuel J. A Manual of Gynæcology. Third Edition.

Cawston, F. Gordon. Bilharzia.

(Edward Arnold \& Co.)

45s. net.

25 s. net.

(John Bale, Sons \& Danielsson, Ltd.) 2s. 6d. net.

Childe, Charles P. Cancer and the Public. (Methuen \& Co., Ltd.) Ios. 6d. net.

Christie, ARThUR C. Röntgen Diagnosis and Therapy.

Dukes, CuthBert. The Bacteriology of Food.

25s. net.

(H. K. Lewis \& Co., Ltd.) 7s. 6d. net.

Ghosh, B. N. (Edited by). Materia Medica and Therapeutics. Tenth

Edition

(H. K. Lewis \& Co., Ltd.)

Glaister, John. Legal Medicine . . (Alexander Stenhouse)

Hare, Hobart Amory. Practical Therapeutics. Nineteenth Edition.

Hutchison, RoberT. Lectures on Diseases (Henry Kimpton)

Edition . . . D Difth

Jellett, Henry. A Practice of Gynæcology. Fifth Editiold \& Co.)

5s. net.

36s. net.

2Is. net.

Lincoln, Oliver Waldo. Sex Hygiene.

(J. \& A. Churchill)

25 s. net.

(John Bale, Sons \& Danielsson, Ltd.)

Paramore, R. H. The Statics of the Female Pelvic Viscera. Vol. II.

Is. net.

Saugman, Prof. C. Vejlefjord Sanatorium.

(H. K. Lewis \& Co., Ltd.) 24s. net.

(John Bale, Sons \& Danielsson, Ltd.) 7s. 6d. net.

Seelig, M. G. Medicine : an Historical Outline.

(Baillière, Tindall \& Cox) I Is. 6d. net.

Tweedy, E. Hastings, G. T. Wrench, and Bethel. Solomons.

Practical Obstetrics. Fifth Edition. • (Humphrey Milford)

Williams, Leonard. Middle Age and Old Age.

Wilson, P. D., and William A. Cochrane. Fractures and Milford)

2 Is. net. tions 